\title{
The myth of the 'five bloods': from fiction to legal custom in the English royal courts in fourteenth-century Ireland
}

\author{
S.G. HewER*
}

[Accepted 1 July 2018. Published 28 September 2018]

Abstract

Introduction
This paper examines two issues: misconceptions concerning English law in high medieval Ireland; and the invention and mutation of an exceptio (objection) in court which was based on a fabrication. The plea, or defensive claim, was that the plaintiff in a court case was an unfranchised Gael (HibernicalHibernicus) and therefore could not sue a civil writ in the English king's royal courts in Ireland. This pleading has led some historians to surmise that all Gaels were unfranchised in English Ireland without a personal grant of access from the crown of England. The plea also claimed that only five Gaelic families were allowed to sue in the royal courts. Each time the plea was made, it changed, and after sixty years a defendant claimed that the ancestors of the then current king (Edward III) had granted access to English law only to five Gaelic families. There are many problems with this claim.

Since the subject was addressed by John Davies (1569-1626), historians of medieval Ireland have presumed that there was a general exclusion of all Gaelic people from the English courts in Ireland established c.1200. ${ }^{1}$ This hypothesis partially rests on the exceptio (objection in court) of the 'five bloods'. This objection was a claim by defendants that only five Gaelic families ('bloods') were allowed to use the English royal courts in Ireland. ${ }^{2}$ Over the years the exceptio

\footnotetext{
*Author's e-mail: hewers@tcd.ie

doi: https://doi.org/10.3318/PRIAC.2018.118.11

${ }^{1}$ John Davies, A discovery of the true causes why Ireland was never entirely subdued: [and] brought under obedience of the crown of England until the beginning of his majesty's happy reign (1612), ed. J.P. Myers (Washington, D.C., 1988), 124-30.

${ }^{2}$ These 'five bloods' were the patrilineal families of what were considered the five most powerful kings in Ireland and due to their nobility, power or status they were to be regarded as free to use the English courts. No thirteenth-century source names them, but an early modern source claims that the five were the Uí Néill of Ultonia, the Uí Mhaoilsheachlainn of Mide (Meath), the Uí Chonchobhair of Connacht, the Uí Bhriain of Tuadhmhumha (Thomond) and the Meic Mhurchadha of Laighin (Leinster). A.J. Otway-Ruthven rightly observed that these were not the most powerful Gaelic kings
} 
grew to include a supposed royal grant from the crown of England to the 'five bloods' and it changed from a denial of the ability to sue a writ in the royal courts to a general exclusion from any aspect of English law. This paper is the first to examine the seventeenth-century documentary evidence for the putative grant. I argue that it was not authentic and proceed to analyse the surviving medieval evidence of an invented and fluid legal custom.

English law in the thirteenth and fourteenth centuries involved a contention of written law with customary (unwritten) law which allowed for repeated claims in and out of court to eventually be considered 'the law' if enough people decided that the claim would benefit society-even if the 'custom' [the contemporary term] was based on a lie. Nearly fifty years ago Michael Clanchy observed the tension in twelfth-century England which arose from the advent of recorded law and legal records which disrupted the practices of customary law. ${ }^{3}$ Clanchy argued that customary societies inherently changed historical facts to meet present problems; they were not hampered by objectivity. ${ }^{4} \mathrm{He}$ used the phrase 'good old laws' to indicate instances when recently invented traditions were given false antiquity to buttress current politics and he noted that after the advent of written law in England the mores of a customary society did not disappear overnight. The English law in Ireland was no different. The 'common law' allowed for regional customs; it was neither completely codified nor immutable. Edward I of England mandated the royal courts in Ireland to enforce local custom in relevant court cases. ${ }^{5}$ Another aspect of English law has been misunderstood by historians of medieval Ireland: access to English law and access to the English royal courts were not equivalent. The manorial courts [on manors within the English lordship of Ireland] used English law and the unfree tenants [nativi] used these courts. These nativi used English law, but could not sue a writ or answer one in a royal court, just as villeins in thirteenth-century England. To claim that someone could not sue a writ in a royal court is not the same as claiming that that person did not have access to English law.

This essay explores two different types of sources to appraise the claim that 'five bloods' were granted access to the English courts in Ireland. The first

in thirteenth-century Ireland: A.J. Otway-Ruthven, 'The native Irish and English law in medieval Ireland', in Peter Crooks (ed.), Government, War and Society in Medieval Ireland (Dublin, 2008), 141-52: 144-5.

${ }^{3}$ M.T. Clanchy, 'Remembering the past and the good old law', History: the Journal of the Historical Association 55 (184) (1970), 165-76. Many thanks to Peter Crooks for informing me of this article.

${ }^{4}$ Eric Hobsbawm noted that modern societies have 'invented traditions' on a regular basis, perhaps more often than previous societies. This may mean that Clanchy's 'literate societies' are not as objective as he thought: Eric Hobsbawm, 'Mass-producing traditions: Europe, 1870-1914', in Eric Hobsbawm and Terence Ranger (eds), The invention of tradition (reprint, Cambridge, 2013), 263-307.

${ }_{5}^{5}$ James Mills (ed.), Calendar of the justiciary rolls or proceedings in the court of the justiciar of Ireland, 1305-7 (CJRI, 1305-7) (Dublin, 1914), 19, 76-7. 
are early modern 'notes' which profess to be copies of medieval records, but have numerous blunders. The claims in the seventeenth-century notes are evaluated against the contemporary (thirteenth- and early fourteenth-century) political situation in Ireland. Secondly, the instances when a 'five' plea was used in an English royal court in Ireland are examined. These records reinforce the theory that there was no royal grant to the 'five bloods'.

The seventeenthcentury documentation and its problems
The only surviving documentary sources which name the supposed five 'bloods' date from the late sixteenth or early seventeenth century. British Library, Cotton MS Titus B XI is a collection of medieval parchments and early modern 'copies' in two parts. The first folio of part one states that Titus B XI contains 'Original letters \& Papers concerning Ireland until the end of Edward VI \& Queen Mary.' Robin Flower mentioned Titus B XI in his article on surviving manuscripts of Irish material, but he also claimed that folios 1-71 were 'originals' when in fact they are not. ${ }^{7}$ Flower concluded that the copies of medieval records in B XI were written by George Carew (1555-1629) based on an analysis of the script. ${ }^{8}$ These 'copies' are written in early modern English and have many linguistic problems. Titus B XI has been repaginated several times and was bound into two parts in the twentieth century. Within the folios of copies there are two 'notes' (A.J. OtwayRuthven's term), one in part one and one in part two. The first one is well known to historians of medieval Ireland. ${ }^{9}$ This record claims that:

Anno 3 H 3: in Archivis Cast' Dublin'

Rex H 3 ।in anno/ regnum sui 3 [1218-19]: by especial graunt enfraunchised and enabled 5 principal/ bloods or septs of the Irishrie, to take the benefit of the lawes of England viz: onealo de Ultonia [Uí Néill of Ulster], Omalaghlin de midia [Uí Mhaoilsheachlainn of Mide/Meath], Oconnoghor de Connachia [Uí Chonchobhair of Connacht], Obrien de Tothmonia [Uí Bhriain of Tuadhmhumha/Thomond], et M`c/Mourgho de Lagenia [Meic Mhurchadha of Laighin/Leinster] ${ }^{10}$

As Otway-Ruthven observed, the five 'bloods' named in this record are questionable. The record cites the Dublin Castle Archives as its source. There is no record of a plea roll or patent roll from 3 Henry III having ever existed in Bermingham Tower (Dublin Castle). It could have been lost over the centuries,

\footnotetext{
${ }^{6}$ British Library (BL), Cotton MS Titus B XI, pt 1, f. 1r.

${ }^{7}$ Robin Flower, 'Manuscripts of Irish interest in the British Museum', Analecta Hibernica 2 (1931), 292-340: 296. The British Library website notes that in part $1 \mathrm{ff} 2-28,45,49$ are parchment and ff $1,29-44,46-8,50-83$ are paper, and that all folios in part 2 are paper: http://searcharchives.bl.uk/IAMS_VU2:IAMS040-001103529 (24 April 2018).

${ }^{8}$ There is at least one problem with this theory, see below, 11, 13-14.

${ }^{9}$ Professor Otway-Ruthven mentioned it in 1950: Otway-Ruthven, 'Native Irish', 144-5.

${ }^{10} \mathrm{BL}$, Cotton MS Titus B XI, pt 1, f. 70v.
} 
but it did not exist in 1810 when the Records Commission made a list of every surviving medieval record. ${ }^{11}$ The oldest surviving record at that point was a pipe roll from 13 Henry III [1228-9]. ${ }^{12}$ A copy of the pipe roll for 14 John was made for James Ware in the mid-seventeenth century. ${ }^{13}$ It appears that there were no surviving patent rolls, close rolls or plea rolls from 3 Henry III at that time either (1678), and the pipe rolls for 2-3 Henry III were also absent. ${ }^{14}$ An inventory of 'old' (antiquorum) Irish memoranda states that no royal record from 3 Henry III survived in the Bermingham Tower in 1678, which was relatively soon after the Cottonian note was made. There is no mention of such a grant in the charter rolls, patent rolls, close rolls or fine rolls in the Public Record Office (UK), nor is the supposed grant from 1218 listed or referenced in any contemporary records from English Ireland. ${ }^{15}$ It is highly doubtful that the Dublin administration or the crown of England would issue such a grant without significant remuneration. Yet, no reference to any debt for this grant exists. In the surviving records from the Irish Chancery there are no mentions of 'five bloods' or 'five lineages'. If there was a stand-alone charter from Henry III's regency in 1218, then it should have been included with the other 'ancient' grants and charters on the 'Antiquissime Roll'. ${ }^{16}$ This was a roll of grants and charters to 'prominent' persons in Ireland, many of which were granted under the great seal of England and not the Irish seal. ${ }^{17}$ It is also highly problematic that John Davies did not cite or mention this supposed grant in his propagandistic treatise (A discovery) in 1612. This 'grant' would have bolstered Davies's argument and it therefore would have been remiss of him not to include it.

The next problem is that the note in Cotton Titus is in modern English, and if we undo the supposed translation, the form and phraseology do not match contemporary grants. John Davies's work, which is analysed below, demonstrates

\footnotetext{
${ }^{11}$ The sixth, seventh, eighth, ninth, and tenth reports from the commissioners appointed by his majesty to execute the measures recommended in an address of the House of Commons, respecting the public records of Ireland, 1816-1820 (London, 1820), 79-136, 383-430, $521-58$.

${ }^{12}$ Eighth report from the commissioners, 125; 35th Report of the deputy keeper of the public records and keeper of the state papers in Ireland (RDKPRI) (Dublin, 1903), 29-33. ${ }^{13}$ Oliver Davies and D.B. Quinn (eds), 'The Irish pipe roll of 14 John, 1211-1212', Ulster Journal of Archaeology 4, supplement (1941), 1-76: 2.

${ }^{14}$ Davies and Quinn, 'Irish pipe roll', 75.

${ }^{15}$ Such as J.T. Gilbert (ed.), Historic and municipal documents of Ireland, A.D. 1172-1320 (London, 1870); J.T. Gilbert (ed.), Chartularies of St. Marys abbey, Dublin with the register of its house at Dunbrody and annals of Ireland (2 vols, London, 1884).

${ }^{16}$ Peter Crooks (ed.), A Calendar of Irish Chancery Letters, c.1244-1509 (CIRCLE), Antiquissime Roll. Cf. there are three grants from John before he was king of England, one from Richard son of Gilbert de Clare (nowadays called 'Strongbow') on behalf of Henry II, and a confirmation of a grant by Henry II in this roll: Crooks (ed.), CIRCLE, Antiquissime Roll, nos 4, 5, 16, 52, 53.

${ }^{17}$ Peter Crooks, 'The Irish Chancery Rolls: introduction', CIRCLE (https://chancery. tcd.ie/content/irish-chancery-rolls\#introduction) (20 Dec. 2017).
} 
that phraseology is pertinent to this examination. ${ }^{18}$ The dating is at the beginning (instead of the end), there is no 'datum apud' or witnesses, and the phrase 'enfranchised and enabled' is not found in any other contemporary grant. The usual phraseology is: '[this/these named person/people] may use and enjoy all of the liberties and free customs of the English in Ireland' (Latin: quod [name]...... utantur et gaudeant omnibus libertatibus et liberis consuetudinibus quibus Anglici nostri utuntur in Hibernia). ${ }^{19}$ The grant would typically conclude with a location and a list of witnesses. Assuming that the person who wrote the note in the seventeenth century made a substantive translation that drastically altered the wording (and did not simply fabricate the record), there are still other problems.

There is an issue with the political situation in Ireland at that time (1218). In 1210, during King John of England's visitation of Ireland, he received the submission of King Cathal Croibhdhearg Ó Conchobhair of Connacht; he was offered the military assistance of King Aodh Méith Ó Néill of Tír Eoghain (not Ulster); and he knighted Donnchadh Cairbreach Ó Briain of Thomond. ${ }^{20}$ But the itineration did not end well. The English king famously was furious at Ó Conchobhair for refusing to hand over his first-born son as a hostage and John failed to negotiate a submission by Ó Néill. In regard to the other two families, the Meic Mhurchadha were completely absent from the political scene. ${ }^{21}$ Further, Cormac mac Airt Uí Mhaoilsheachlainn defeated several English armies between 1210 and 1215, but was never called 'king of Mide'. ${ }^{22} \mathrm{He}$ was not inclined to ask for acceptance by the English and may have attacked Maolsheachlainn Beag Ó Maoilsheachlainn (who was the king) in 1214 for allying with the English. Many of the other interactions with the Dublin administration were not favourable to the Gaelic families who had been co-operative, and in January 1216/17 the Dublin administration attempted to ban any Gaelic man from being promoted

\footnotetext{
${ }^{18}$ Davies mistranslated the Latin in a defensive plea in court (the defendant claimed that only 'five bloods' could use the English law in Ireland) into a legal rule: below 11, 22-3.

${ }^{19}$ An Chartlann Náisiúnta, The National Archives (ACN), RC 7/11, 202-3. Other letters state that the grantees may 'have' (habeant) English law or use 'English law and customs' (leges et consuetudines Anglicanam).

${ }^{20}$ Seán Duffy, 'King John's expedition to Ireland, 1210: the evidence reconsidered', Irish Historical Studies (I.H.S.) 30 (117) (1996), 1-24: 4-5.

${ }^{21}$ After the death of Diarmaid Mac Murchadha in 1171, Muircheartach 'na Maor' Mac Murchadha was king of Uí Cheinnsealaigh (with the possible approval of 'Strongbow') until 1193. During the year of the supposed grant (1218) the only known Mac Murchadha was a 'Maurice' who witnessed a grant to the church of St Mary and St Columba of Inistioge. He was not labelled a 'king': Emmett O'Byrne, War, politics and the Irish of Leinster, 1156-1606 (Dublin, 2003), 28.

${ }^{22}$ W.M. Hennessy (ed.), The Annals of Loch Cé: a chronicle of Irish affairs, 1014-1590 (reprint, 2 vols, Dublin, 1939), vol. 1, 240-53; John O'Donovan (ed.), Annala rioghachta Eireann: Annals of the kingdom of Ireland from the earliest period to the year 1616 by the four masters (AFM) (3rd ed., 7 vols, Dublin, 1990), vol. 3, 172-83.
} 
to a position in a cathedral church or obtaining a bishopric. ${ }^{23}$ This was one of the last comments by the administration which might demonstrate acceptance of certain Gaels before the date of the supposed grant.

Two further problems are that the Uí Néill, strictly speaking, did not live in, or rule, Ultonia and the Uí Mhaoilsheachlainn were a declining power in the midlands by that date. To the English in Ireland Ultonia (Ulster) was based on Ulaidh, the Ó Duinnshléibhe territory east of the River Bann, which was distinct from Tír Eoghain, the territory to the west, contested by the Uí Néill and Meic Lochlainn, and the region of Tír Conaill further west, over which the Uí Dhomhnaill would shortly emerge as rulers. ${ }^{24}$ We know that the English did not consider the lands west of Ultonia as part of Ulster (in the modern sense) from references in other surviving records. On the pipe roll for 14 John (1211-12) a fine from Ó Néill, along with one from the 'king of Connacht', was recorded under the liberty of Meath and not under Ulster. ${ }^{25}$ When John of England granted Ó Néill lands to Thomas of Galloway in 1213 these were from 'Kenlion' (Cineál Eoghain) not Ulster. ${ }^{26}$ In 1260 the Dublin Exchequer recorded a debt from 'Bren Onel, regulus of Keneloun' (minor king of Cineál Eoghain). ${ }^{27}$ In 1275 several Gaelic kings of the north sent a letter to Edward I of England. These kings were Niall [Cúlánach] Ó Néill, rex de Yncheun (Inis Eoghain, the Inishowen peninsula), G. Mac Duinnshléibhe, rex Hibernicorum Ultonie (of the Gaels of Ultonia, i.e., the kingdom of Ulaidh), and four others. ${ }^{28}$ Niall Cúlánach was the brother of Aodh Buidhe Ó Néill, king of Tír Eoghain. And even later the English referred to an Ó Néill as 'dux Hibernicorum de Tyrowyn' (leader of the Gaels of Tír Eoghain) in 1314..$^{29}$ Ultonia did eventually include 'Twescard' (Túaiscert) which extended west of the River Bann towards Inis Eoghain. ${ }^{30}$ Also, the Uí Néill were not inclined to join English Ireland at that time (1218-19).

\footnotetext{
${ }^{23}$ H.S. Sweetman (ed.), Calendar of Documents relating to Ireland, 1171-1307 (Cal. Docs Ire.) (5 vols, London, 1875-86), vol. 1, no. 736. John Watt noted that the Dublin administration and the regency in England tried to prevent Gaels from being elected to bishoprics between 1216 and 1226: J.A. Watt, The church in medieval Ireland (Dublin, 1972), 71-6.

${ }^{24}$ The English in Ireland sometimes called these kingdoms Cineál Eoghain and Cineál Chonaill, but this may have been an act of recognising that the Gaelic kings usually ruled a group of people and not specific lands: Cal. Docs Ire., vol. 1, nos 468, 1001, 1048; J.T. Gilbert (ed.), Facsimiles of national manuscripts of Ireland (4 vols, London, 1874-84), vol. 2, plate 73 .

${ }^{25}$ Davies and Quinn (eds), 'Irish pipe roll', 36-7.

${ }^{26}$ Cal. Docs Ire., vol. 1, no. 468.

27 35th RDKPRI, 40.

${ }^{28}$ Thomas Rymer, Federa: conventiones, litere, et cujuscunque generis acta publica, inter reges Anglice et alios quosvis imperatores, reges, pontifices, principes, vel communitates ab ingressu Gulielmi I in Angliam a.d. 1066 ad nostra usque tempora habita aut tractata (3rd ed., 4 vols, London, 1816-39), vol. 1, pt 2, 520-1.

${ }^{29}$ Rymer, Fodera, vol. 2, pt 1, 245.

${ }^{30}$ Gilbert (ed.), Facsimiles, vol. 2, plate 73.
} 
They were preparing themselves to halt the westward advance of the English of Ultonia into Tír Eoghain. ${ }^{31}$ For that matter, the Uí Mhaoilsheachlainn were no longer the de facto kings of Mide (Meath) when it was invaded by Hugh de Lacy. ${ }^{32}$ They had lost the kingship of Mide to Ó Ruairc and Ó Conchobhair and subsequently the English did not call the Uí Mhaoilsheachlainn 'king' or 'leader' ( $d u x)$ of Mide. ${ }^{33}$ The place names the English used for Meath, Ulster, and Tír Eoghain are important because the supposed grant in 1218 was by the English. Some Uí Mhaoilsheachlainn became clients of the Uí Chonchobhair and some attacked English settlements. ${ }^{34}$ Becoming clients of the Uí Chonchobhair demonstrates the deterioration of Ó Maoilsheachlainn power and prestige. Perhaps more importantly the Uí Mhaoilsheachlainn were no longer an interprovincial power long before 1169. After the tenth century, with the exception of Máel Sechlainn (d. 1022), the Uí Mhaoilsheachlainn of Clann Cholmáin did not maintain control of territory outside of the midlands, did not consistently control all of the midlands, and were regularly invaded or made clients by more powerful kings. ${ }^{35}$

The Uí Chonchobhair were kings of Connacht and the English recognised this. King Cathal Croibhdhearg Ó Conchobhair famously negotiated with King John, and surrendered rights, in order to obtain a charter for Connacht in 1215. ${ }^{36}$ But the English of Meath invaded Connacht in 1218 and Cathal did not sue the invaders or petition the regency government (ruling England during

\footnotetext{
${ }^{31}$ Katharine Simms, 'The O Hanlons, O Neills and the Anglo-Normans in thirteenthcentury Armagh', Seanchas Ardmhacha: Journal of the Armagh Diocesan History Society 9 (1) (1978), 70-94: 74-5.

32 C.T. Veach, 'Henry II's grant of Meath to Hugh de Lacy in 1172: a reassessment', Ríocht na Midhe 18 (2007), 67-94: 75-6.

${ }^{33}$ Veach, 'Henry II's grant', 75-6. The Gaelic annals still called the Uí Mhaoilsheachlainn kings of Mide after 1169, and Cormac mac Airt, while not the king, was very hostile to the English of Meath and his Gaelic rivals: O'Byrne, War, politics and the Irish, 48-9.

${ }^{34}$ Maolsheachlainn Beag Ó Maoilsheachlainn, 'king of Tara', accepted tuarustal from Ruaidhri Ó Conchobhair in 1189: AFM, vol. 3, 86-7; for attacks on the English, see n. 22 above.

${ }^{35}$ Paul Walsh, 'The Ua Maelechlainn kings of Meath', The Irish Ecclesiastical Record 57 (1941), 165-83: 165-78; Liam Cox, 'The Ó Maeleachlainn kings of Meath', Riocht na Midhe 5 (2) (1972), 22-53: 22-7; Donncha Ó Corráin, Ireland before the Normans (Dublin, 1972), 96-101, 117-26, 131, 136; M.T. Flanagan, Irish society, Anglo-Norman settlers, Angevin kingship: interactions in Ireland in the late twelfth century (Oxford, 1989), 224-5; 224, n. 165.

${ }^{36}$ Helen Walton, 'The English in Connacht, 1171-1330', unpublished $\mathrm{PhD}$ thesis, University of Dublin, 1980, 44-6; eadem [named as Helen Perros], 'Connacht and the Anglo-Normans, 1170-1224', in T.B. Barry, Robin Frame, and Katharine Simms (eds), Colony and frontier in medieval Ireland: essays presented to J.F. Lydon (London, 1995), 117-38: 133; Freya Verstraten, 'Both king and vassal: Feidlim Ua Conchobair of Connacht, 1230-65', Journal of Galway Archaeological and Historical Society 55 (2003), 13-37: 14. The charter did not make Cathal an Englishman or 'enfranchise' him. It had a stipulation that if he did not provide good service (quamdiu nobis bene servierint), he could be completely disseised without a court judgment.
} 
Henry III's minority) for restitution. ${ }^{37}$ In 1220 Geoffrey de Marisco, the justiciar or chief governor of Ireland, recommended to the regency that Cathal be left in possession of Connacht instead of allowing Richard de Burgh to conquer it. ${ }^{38}$ In 1224 the regency granted that Cathal would be protected from Walter de Lacy as long as the former was faithfully serving the king of England. ${ }^{39}$ On the other hand, Cathal's son, Aodh, forfeited Connacht for failing to appear in court and then attacking the justiciar's son at a parley in $1226 .{ }^{40}$ Aodh had been summoned to appear in court under the conditions of the 1215 grant, and not due to any 'enfranchisement' in 1218.

The Uí Bhriain of Thomond could have been granted access to the English courts in 1218, but it appears they were already regarded as free and accepted (had access to the English courts) in $1215 .{ }^{41}$ While the Uí Bhriain appear to have had good relations with Dublin in 1218, the justiciar, Geoffrey de Marisco, imposed his own candidate, his nephew Robert Travers, into the bishopric of Killaloe (most of Thomond) in $1217 .{ }^{42}$ It appears that at the same time de Marisco built a castle in Killaloe to secure his nephew's intrusion. The regency in England approved of the intrusion, and it took several papal admonitions and eventual deposition by the papal legate to remove Travers from Killaloe in 1221. Any grant to the Uí Bhriain did not have the justiciar's backing. If the 1218 grant was real, it was cancelled afterwards. In 1250 Henry III sent a letter to the justiciar stating that if Conchobhar Ó Briain paid a fine of 2,200 marks, the latter could hold his ancestral lands at the king's pleasure which Ó Briain's father had formerly held in fee by charter. ${ }^{43}$ If the Uí Bhriain were 'enfranchised', Conchobhar surely could have sued to hold the lands as his father did.

If we set aside all of these issues for a moment, there is still the problem of the choice of the five. These were not the five most powerful Gaelic kings, nor the most faithful or supportive of the English in Ireland. If the supposed grant was an attempt to placate the most powerful kings and stabilise the English settlements, then it should have been to the Meic Charthaigh, Uí Bhriain, Uí Chonchobhair, Uí Dhomhnaill and Uí Néill. Donnchadh Ó Briain helped the English 'of Munster and Leinster' fight Diarmaid Mac Carthaigh in $1214 .{ }^{44}$ The Uí Néill of

\footnotetext{
${ }^{37}$ Walton, 'English in Connacht', 48.

${ }^{38}$ Walton, 'English in Connacht', 47.

${ }^{39}$ Perros, 'Connacht', 134. Dr Perros also noted that the regency in England could not make any permanent grants under the great seal.

${ }^{40}$ Walton, 'English in Connacht', 57-63.

${ }^{41}$ Cal. Docs Ire., vol. 1, nos 629, 649, 669, 673.

${ }^{42}$ Aubrey Gwynn and D.F. Gleeson, A history of the diocese of Killaloe (Dublin, 1962), $223-32$.

${ }^{43}$ Cal. Docs Ire., vol. 1, no. 3054.

${ }^{44}$ Séamus Ó hInnse (ed.), Miscellaneous Irish annals (a.d. 1114-1437): fragment from Mac Carthaigh's Book and two fragments from Rawlinson B.488 (Dublin, 1947), no. 1214.1.
} 
Tír Eoghain did not have hegemony of the north in 1218. They contended with the Uí Dhomhnaill, Meic Lochlainn (or Uí Lochlainn), and the English of Ulster. ${ }^{45}$ Cathal Ó Conchobhair and Maolsheachlainn Beag Ó Maoilsheachlainn showed no signs of 'rebelling' against the English crown, and the Meic Mhurchadha were William Marshal's cousins and tenants and entirely missing from political or military affairs in 1218. Donnchadh Ó Briain had been serving 'faithfully' in English armies against English and Gael alike. But the Meic Charthaigh were receiving requests and demands from the administration, and fighting for and against the English. ${ }^{46}$ They had clear involvement in Irish politics and their changing 'allegiance' would have been concerning to the administration. Even more problematic is that the Meic Charthaigh could use the English courts and held lands in fee. ${ }^{47}$

There are two letters from the regency in England (November 1217 and July 1221) that cast doubt on the supposed 'five bloods'. The first letter ordered the justiciar and archbishop of Dublin to impose an aid on the kings of Connacht (Ó Conchobhair) and Thomond (Ó Briain) and other kings of Ireland. ${ }^{48}$ This record may reinforce the hypothetical grant for the two named kings, but it does not substantiate the claim for the other three. And in 1221 the regency sent letters to the justiciar and magnates demanding rents, fines and escheats for the previous five years. At the top of the list were King Cathal [Ó Conchobhair] of Connacht, King Aodh [Ó Néill] of Cineál Eoghain, Donnchadh Ó Briain, Muircheartach Ó Briain, Diarmaid Mac Carthaigh and Lughaidh mac Donnchadha ${ }^{49}$ Not only were the Uí Mhaoilsheachlainn and Meic Mhurchadha missing, but also Mac Carthaigh was included and the regency recognised that Aodh Ó Néill was king of Cineál Eoghain and not Ulster.

Finally, there is no confirmation of the grant by Henry III once he came of age. Any and all grants made by the regency government only had effect until Henry was able to confirm and renew them; they were not permanent. The absence of any confirmation from Henry III in $c .1228$, the absence of any mention of this 'grant' by John Davies, and the numerous other problems already mentioned indicate that the first 'note' was either a forgery by the Cottonian clerk or a copy of an earlier forgery which was drafted to confirm retroactively and protect the 'five bloods' plea used in the royal courts in the early fourteenth century.

\footnotetext{
${ }^{45}$ Simms, 'O Hanlons', 74-8.

${ }^{46}$ G.H. Orpen, Ireland under the Normans, 1169-1333 (with introduction by Seán Duffy, Dublin, 2005), 342-53.

${ }^{47}$ Cal. Docs Ire., vol. 1, nos 766, 1001, 2032, 2716; S.G. Hewer, 'Justice for all? Access by ethnic groups to the English royal courts in Ireland, 1252-1318', unpublished $\mathrm{PhD}$ thesis, University of Dublin, 2018, 86, 106, 122-4.

${ }^{48}$ Cal. Docs Ire., vol. 1, no. 810.

${ }^{49}$ T.D. Hardy (ed.), Rotuli litterarum clausarum in Turri Londinensi asservati (2 vols, London, 1833-44), vol. 1, 476-7. 'Loueth Mac Donewhod' [Lughaidh mac Donnchadha] was probably the same man who was slain by the Uí Chairbre in 1223: Seán Mac Airt (ed.), The Annals of Inisfallen (Dublin, 1988), no. 1223.2. Many thanks to Seán Duffy for providing me with this reference.
} 


\section{Confusion between pleas in court and a grant}

The second note in Cotton MS Titus B XI concerning the 'five bloods' is also problematic. Written in the same hand, it claims that five Gaelic families were 'enfranchised' in 3 Edward II (1309-10). It runs as follows:

Archivis Cas' Dublin' 3: Ed: 2

Onealo of Ulster
Obrien of Tomend
OMalaghlin of Medhe
OConnogher of Connaght
Obrien of Tomond
$\mathrm{M} \backslash$ /Murogho of Leinster

were enfranchised as well for themselves as for the rest of there surnames, to have the benifitt of the Englishe Lawes, as Englishe men: ${ }^{50}$

The first thing to note is that this record does not label the five families as the 'five bloods'. It has the same issue with translation as the earlier record: it does not match contemporary grants of access to the English courts in Ireland. Another problem is that it contradicts the earlier record. It is clearly not a confirmation of the supposed earlier grant. Possibly more important is the fact that there is no mention of a grant (or confirmation) from 1309 in the patent rolls, close rolls, charter rolls or fine rolls in the Public Record Office. And, as is well known, a petition in 1290 claimed that grants of access to the English courts in Ireland were not free or cheap..$^{51}$ There should be records of the exchequer seeking payments from the five families for this 'enfranchisement', but there are none. In none of the letters (c.1309) to these families did the English or Irish chanceries call these Gaels the 'five bloods'.

There is, however, a possibility that the second Cottonian note is a miscopy of a medieval record. In 1810 there were six surviving Dublin Bench rolls from 3 Edward II (Records Commission roll nos 93-8) in Dublin Castle. ${ }^{52}$ Several seventeenth-century historical commentators refer to a court roll from 1309, al-

\footnotetext{
${ }^{50} \mathrm{BL}$, Cotton MS Titus B XI, pt 2, f. 106r. This note has not been mentioned previously. This 'grant' may be based on the supposed 1309 court record (analysed below, 22-3), but the order of the 'five' in that record differs from this record.

${ }^{51}$ Maurice Macotyr [Mac Óttairr] asked Edward I to be labelled an 'Ostman' (a GaelicScandinavian Irishman), and then claimed that the king had made $£ 3,000$ in one day from petitioners for access to the English courts in Ireland: Parliamentary Rolls of medieval England (PROME), Edward I, roll 4, m. 1 (http://www.sd-editions.com/ AnaServer?PROME+56227+parlfra.anv) (10 Nov. 2017).

${ }^{52}$ Eighth report from the commissioners, 86. The gaol delivery roll from 3-7 Edward II was calendared and published: M.C. Griffith, Herbert Wood, and A.E. Langman (eds), Calendar of the justiciary rolls or proceedings in the court of the justiciar of Ireland, 130814 (CJRI, 1308-14) (Dublin, 1956), 143-326.
} 
though it could be that only one man looked at the roll and the others copied his mistranslation of the Latin. John Davies claimed that, based on a court case from 1354, all Gaels were 'reputed aliens' except the 'five bloods' who were 'by special grace enfranchised and enabled to take benefit of [English] laws'. ${ }^{53}$ The similarities in phraseology may indicate that the Cottonian clerk (from the 1218 grant) copied Davies, or vice versa. Davies's argument that the 'five bloods' were 'enfranchised' was retroactive. He then confirmed the 'special grant' with a record from 1309 that stated the right to 'enjoy the English law as far as the writs apply' (in a footnote: 'qui gaudeant lege Anglicana quoad brevia portanda') was granted to the 'five septs or bloods'. Davies did not provide most of the pleading or the judgment from either case. In a different record (Clarendon Codex no. 43) we discover that Davies had changed the pleading from two court cases into proof of a grant. ${ }^{54}$ It appears that the Cottonian clerk did the same, but we cannot tell if this was independent of Davies or a copy of the claim in $A$ discovery. Another record, by George Carew, does contain further evidence of the 1309 case and the misunderstanding by seventeenth-century historians. ${ }^{55}$ Davies continued to note that, despite the records he mentioned, some of the Uí Néill were required to purchase grants of access to the English courts long afterwards. Davies did not claim that the 'five bloods' were to be regarded as 'Englishmen'. This indicates that the Cottonian clerk significantly altered the original wording of the record, at least, and Davies's record indicates that he mistook a plea in court for a grant.

As with the earlier record, the political situation in Ireland in 1309 casts doubts on the authenticity of the supposed grant. Three of the five families were not kings of, or living in, the place the record alleges. In 1309 the Uí Néill were not in Ultonia (despite Domhnall Ó Néill's claim to be the 'rex Hibernicorum Ultonie'): ${ }^{56}$ the Uí Mhaoilsheachlainn were not the most powerful Gaelic family in the midlands; $;^{57}$ and the Uí Chonchobhair had been pushed out of the new English county of Connacht and were left with part of what the English called Co. Roscommon (or 'the [English] king's cantreds') but they continued to use the title 'king of Connacht'. ${ }^{58}$ Since this supposed grant is an English record, it is important that the English did not locate some of the five to the appropriate place (the Uí Néill ruled Tír Eoghain, not Ultonia, and medieval Co. Roscommon

\footnotetext{
${ }^{53}$ Davies, Discovery, 126-7.

${ }^{54}$ Case no. 5 below.

${ }^{55}$ It is examined below in the court records section, below 22-3.

${ }^{56}$ Kenneth Nicholls, Gaelic and Gaelicized Ireland in the Middle Ages (2nd ed., Dublin, 2003), 153. Mr Nicholls dated this to 1306, but the record states 'the first year of the reign of King Edward' and Domhnall was not king of Tír Eoghain until c.1282-3. So this record must be dated to 1307-8: Katharine Simms, 'Gaelic lordships in Ulster in the later Middle Ages', 2 vols, unpublished PhD thesis, University of Dublin, 1976, vol. 2, 682 .

${ }^{57}$ O'Byrne, War, politics and the Irish, 75.

${ }^{58}$ Walton, 'English in Connacht', 60-82, 203-346; Verstraten, 'King and vassal', 13-19, 23-31.
} 
was distinct from the medieval county of Connacht). The supposed grant was to the kings (or possibly 'chiefs': duces) of 'Ulster, Medhe, Connaght, Tomond, and Leinster'. By 1306 the Uí Chonchobhair Failghe, who had replaced the Uí Mhaoilsheachlainn as the regional power of the midlands, were themselves degraded in power and status (after the famous murder of An Calbhach and Muircheartach), and two other families fought to be the most powerful Gaelic kings in the midlands. ${ }^{59}$ The Uí Bhriain were still in Thomond in 1309, but were unlikely to receive a grant from the king of England or the Dublin administration in his name at that time. They were at war-with the English and each otherin Thomond from 1306 until the Battle of Dysert O’Dea (1318) ${ }^{60}$ Domhnall Ó Néill, as we have seen, claimed to be 'king of the Gaels of Ulster', but the English records call the Uí Néill 'rex de Kyneleun' (king of the Cineál Eoghain), 'regulus de Keneloun' (minor king of the Cineál Eoghain), and 'dux Hibernicorum de Tyrowyn' (leader of the Gaels of Tír Eoghain). ${ }^{61}$ The English administration and courts in Ireland did not consider Tír Eoghain as part of Ulster or the Uí Néill as kings of Ulster.

The Meic Mhurchadha may have been in a position to receive a grant in 1309, but the exact date of the supposed grant is important. They were at war with the English in 1302 and Murchadh Ballach Mac Murchadha was slain by Edmund le Butler in 1307. ${ }^{62}$ Muiris Mac Murchadha began to work for the justiciar, John Wogan, c.1309. Muiris fought against Maurice de Cauntetoun's rebellion and the Uí Bhroin, and he was rewarded with money and land grants. ${ }^{63}$ Two other Gaelic families in the same area who were 'enfranchised' by custom, the Uí Bhroin and the Uí Thuathail, were heavily involved with Irish politics at that time. ${ }^{64}$ Richard Ó Tuathail had inherited lands in fee, but had been outlawed and therefore forfeited his lands. This was the law in England. In 1307 the Dublin administration decided to grant the forfeited lands to Murchadh Ó Broin in order to create 'dissension' between the two families. ${ }^{65}$ If the supposed grant in 1309 was from an Irish parliament (and not Edward II), then it is curious that

\footnotetext{
${ }^{59}$ O'Byrne, War, politics and the Irish, 81-3. The liberty of Kildare was forfeited by William de Vescy in 1297 and turned into a royal county at the Dublin parliament of 1297: see Gerard McGrath, 'The shiring of Ireland and the 1297 Parliament', in J.F. Lydon (ed.), Law and disorder in thirteenth-century Ireland: the Dublin Parliament of 1297 (Dublin, 1997), 107-24: 115-16.

${ }^{60}$ J.F. Lydon, 'Land of war' in Art Cosgrove (ed.), A new history of Ireland, vol. ii, 11691534 (Oxford, 1987), 240-74: 253-6.

${ }^{61}$ Rymer, Fexdera, vol. 2, pt 1, 245; Cal. Docs Ire., vol. 1, nos 1840 [misdated to 1230, should be $c .1260-83$ when Fromund le Brun was chancellor of Ireland], 2716; 35th RDKPRI, 40.

${ }^{62}$ CJRI, 1308-14, 11, 22-3, 32, 55; A.J. Otway-Ruthven, A history of medieval Ireland (London, 1968), 218-19.

${ }_{63}$ O'Byrne, War, politics and the Irish, 66-7.

${ }^{64}$ For more on Gaels 'enfranchised' by custom, see Hewer, 'Justice for all', 37-73.

${ }^{65}$ CJRI, 1305-7, 354.
} 
the Uí Bhroin are missing. If the supposed grant was from Westminster, then it is more plausible. The crown of England was not familiar with which Gaelic families were 'enfranchised' by custom or the local politics in Ireland. In 1310 the Meic Mhurchadha were declared 'felons' again and were listed along with the Uí Bhroin and the Uí Thuathail as criminals. ${ }^{66}$

The Cottonian note and Davies's treatise probably refer to the same record-a case in one of the six now-destroyed plea rolls. The reason that no grant from Edward II survives in any of the extant rolls in the UK Public Record Office is because the Cottonian clerk and Davies mistook a plea (defensive claim in court) for a royal grant and subsequent rule of law or court judgment. At the time (1309) pleaders were allowed to 'try out' dilatory and peremptory pleas on the jury and justices, rescind the pleas later, or let them be judged by the court. ${ }^{67}$ Legal arguments were not constrained to one narrative. Defendants could claim that:

the plaintiff is unfree, and if she is free, then she was not in seisin of the tenement on the day alleged, and if she was in seisin, then the lands are not the size that she claims, if the lands are the size that she claims, then she was in seisin on the alleged day of the disseisin...68

As long as all of these pleas were made in the correct order, then the defendant could propose all of the pleas to the justices for a judgment or the jury for a verdict. The court would then determine the validity and veracity of the pleas. There was no penalty for false pleas in most instances. The record from 3 Edward II was probably a court case in which the defendant claimed that only the 'five bloods' could use the English royal courts in Ireland, rather than being an enrolled copy of a royal grant. The Dublin administration clearly did not recognise Ó Néill as king or leader of Ultonia or Ó Maoilsheachlainn as king or leader of Meath, and Ó Briain and Mac Murchadha were not explicitly recognised as leaders of their respective areas (half of Thomond and the Leinster Mountains). By 1300 there were also several other Gaelic noble families with customary (without a royal grant) access to the English royal courts in Ireland. These included the Meic Charthaigh, Uí Bhroin, Uí Thuathail, Meic Mhurchadha of Connacht (not Leinster), and many others. ${ }^{69}$

The second, previously unstudied note may explain the first note. It could be that someone in the fourteenth century made the forged grants, deposited them

\footnotetext{
${ }^{66}$ CJRI, 1308-14, 165.

${ }^{67}$ Paul Brand, 'Judges and juries in later medieval England: the Millon thesis reconsidered', The Journal of Legal History 37 (1) (2016), 1-40. Many thanks to Paul Brand for informing me of his article.

${ }^{68}$ This is a hypothetical example. The author of Bracton also made a list of the order of pleas: G.E. Woodbine and S.E. Thorne (eds), Bracton de legibus et consuetudinibus Anglice: Bracton on the laws and customs of England (4 vols, London, 1977), vol. 4, 245-7, http://bracton.law.harvard.edu/bracton/index.html (28 May 2018).

${ }^{69}$ Hewer, 'Justice for all', 37-90.
} 
in Dublin Castle, and the Cottonian clerk simply calendared them. Another theory is that the second note was drafted as a grant due to a misunderstanding of pleading and grants by the Cottonian clerk. But neither of these theories explains where the supposed 1218 grant originated. John Davies and George Carew mentioned the 1309 court case, but did not mention the putative 1218 grant. This could mean that the Cottonian clerk forged the 1218 grant or that he copied a record which Davies and Carew did not think was legitimate. This is peculiar as Robin Flower thought that the Cottonian clerk was George Carew.

The law evidence
While it is almost certain that English law was formally instituted in the English lands in Ireland (English Ireland) during the reign of John, ${ }^{70}$ the oldest surviving record of Irish court rolls is from 36 Henry III. ${ }^{71}$ The thirty-three year gap (between the first supposed grant and the oldest surviving records) is concerning, but the evidence so far has indicated that the 1218 grant never existed and the 1309 grant was a miscopy of a plea from a court case. The historiographical consensus can be traced to John Davies's claim that all Gaels were denied access to the English courts in Ireland upon the invention of these courts. ${ }^{72}$ There is one exception: Kenneth Nicholls, who argued that in the first half of the thirteenth century free Gaels, and not only the five Gaelic kings, who held free lands in English Ireland were allowed to use the courts. ${ }^{73}$ The problem with Nicholls's argument is that he still accepts the idea of absolute Gaelic discrimination by the English courts in Ireland - the difference being that Nicholls argued that it was a later phenomenon than previously thought. ${ }^{74}$ The surviving court records do not support the supposition that all Gaels without a grant of access were unfranchised or, worse, reduced to bondage (nativitas). In the oldest surviving court records (1252) there was an attempt to quash a writ of novel disseisin by a Gaelic man, Neivinus Mac Oel [Neamhain Mac Fhoghail?]. ${ }^{75}$ Neivinus impleaded Patrick de Courcy, Geoffrey de Courcy and Milo de Courcy for a carucate (c.120 medieval acres) of land with appurtenances in Glynardale, Co. Cork. Geoffrey did not appear and either the assize proceeded against him by default or Patrick answered as his bailiff. Patrick (and probably Milo) came to court and replied to the assize that Neivinus was a Hibernicus et nativus (Gaelic man and an unfree man), and therefore they did not have to respond to the assize. Neivinus replied that he was a liber homo (free man).$^{76}$ Patrick then pleaded that Neivinus was a

\footnotetext{
${ }^{70}$ Paul Brand, 'Ireland and the literature of the early common law', in idem, The making of the common law (London, 1992), 445-64.

${ }^{71}$ This record is a copy of the now-destroyed original roll: ACN, RC 7/1, 119-221.

${ }^{72}$ Hewer, 'Justice for all', 3-9.

${ }^{73}$ Kenneth Nicholls, 'Anglo-French Ireland and after', Peritia 1 (1982), 370-403: 371-7.

${ }^{74}$ Some of the court cases which demonstrate free Gaels using the English royal courts after 1250 are analysed below, 23-4.

${ }^{75} \mathrm{ACN}, \mathrm{RC} 7 / 1,144-5$.

${ }^{76}$ libero homo in MS.
} 
bastard indicating that the Hibernicus et nativus plea was not going to work and that Neivinus had the right to sue and plea in court. Neivinus's counterplea to Patrick does not survive, but the case continued and Neivinus put himself on the assize (allowed the assize jury to determine the verdict). Paul Brand noted that Patrick's second plea was inappropriate. ${ }^{77}$ Since the writ was for novel disseisin, Neivinus's legitimacy did not pertain to the assize. The itinerant court ordered that the case was respited until the justiciar could rule on it. In the meantime, or so it appears, Patrick de Courcy convinced Neivinus to drop the case in return for a court-witnessed grant of the lands in question. When the court resumed, Neivinus withdrew his writ, and he and his pledges to prosecute were amerced (which was standard procedure). Then the court witnessed de Courcy's grant to Neivinus. Neivinus performed homage and service to de Courcy and was granted the carucate in fee to hold from de Courcy and his heirs forever for rent. This grant sealed Neivinus's legal status for life and his heirs' status for perpetuity. $\mathrm{He}$ had a court-witnessed grant in fee of free lands protecting his free status and the court roll could be called to corroborate this. Subsequently, no one could successfully allege that Neivinus was a nativus.

The plea 'est Hibernical-us et natival-us' has been noticed by some historians, but most seem to have misread it as 'Hibernical-us est natival-us' and they subsequently thought that the 'est Hibernical-us' plea was a sufficient substitute. ${ }^{78}$ These pleas were fundamentally different. The idea of denying unfree people ( $n a-$ tivi) access to English royal courts (in England) predates the advent of the English in Ireland, and the 'common law' practice was in full force when the surviving court records from Ireland begin in $1252 .{ }^{79}$ There was also, just as in England, the ability of defendants to present dilatory or peremptory pleas in response to writs. The 'est Hibernicus et nativus' plea used in Neivinus's case did not end the pleading and the subsequent grant demonstrates that it was completely false. Pleading could continue after dilatory or peremptory pleas. So the fact that some cases were decided entirely on a plea and others examined the plea and continued on to the facts of the case indicates that the est Hibernical-us plea was not universally conceptualised. There is only one instance when a royal court labelled the plea 'peremptory'. ${ }^{80}$ The focus of this analysis is whether the royal courts decided that the 'five bloods' plea was a legal fact or not, and to contextualise the pleading and the putative grants to the 'five bloods'. It appears that none of the historians who analysed Gaels under medieval English law realised that the est Hibernical-us plea was not peremptory (even if the justiciar determined it was once) because even

\footnotetext{
${ }^{77}$ Many thanks to Paul Brand for his comments on this case.

${ }^{78}$ The traditional histories left women out. To combat this trend I use both declensions in references to the forms of writs or pleas. For histories which have conflated 'est Hibernical-us' with 'est Hibernical-us et natival-us', see Hewer, 'Justice for all', 9-10.

${ }^{79}$ The term nativi was later replaced by villani (villeins) in England in the thirteenth century, but the former remained in use in English Ireland.

${ }^{80}$ James Mills (ed.), Calendar of the justiciary rolls or proceedings in the court of the justiciar of Ireland, 1295-1303 (CJRI, 1295-1303) (Dublin, 1905), 158.
} 
if the plea was successful, then the Hibernical-us could simply purchase a royal grant of access to the courts. The issue was not settled forever. ${ }^{81}$

From 1252 until 1294 people were, occasionally, alleged to be unfree in the English royal courts in Ireland, and the practice continued well into the fourteenth century. The free Gaels can be seen in the court records during this time..$^{82}$ But in 1295 a new objection was trialled by defendants: 'est Hibernica et non de quinque progenies' (the plaintiff is a Gael and not one of the five lineages). ${ }^{83}$ This was a profound change. Defendants no longer claimed that the plaintiff was unfree and barred from suing under the rule of law in England. They had invented a new objection which did not exist in the 'common law', a purely ethnic objection to answering a writ. A few years later the new plea split into two legal paths. A few defendants tried to alter the 'non de quinque progenies' plea (into the 'five bloods' plea) and others attempted a less specific 'est Hibernical-us' plea without the rider. The latter first appears in the records in $1297 .{ }^{84}$ These new pleas did not end the practice of the exception of 'naifty' (alleging bondage). That plea continued for some time. ${ }^{85}$

In the Dublin Bench in 1295 Mabel and her husband, William Auncel, sued Henry Fulley and his wife, Margery, for a third of twenty acres in Corrstown, Co. Dublin, which was Mabel's dower from her previous marriage. ${ }^{86}$ Henry and Margery appeared and pleaded that they did not have to respond to the writ because Mabel was a Hibernica and not from one of the five Gaelic lineages who could legally bring writs in a royal court (quinque progeniebus Hibernicis quibus

\footnotetext{
${ }^{81}$ Professor Brand explained to me that a peremptory plea was not defined by stopping all pleading (as some legal scholars have suggested), but instead was a plea that, if successful, permanently ended a case. The plaintiff could not purchase a different writ (as she/he could if defeated by a 'wrong name in writ' dilatory plea). Some Hibernici purchased grants of access to the royal courts in Ireland and then sued people: Hewer, 'Justice for all', 252-3. We can compare these Hibernici to the nativi (in England and in English Ireland) who could not purchase a royal manumission because that belonged to their lord and not the king. Many thanks to Paul Brand for his comments on peremptory pleading.

${ }^{82}$ Hewer, 'Justice for all', 37-73.

${ }^{83}$ The English settlers in medieval Ireland refused to call the Laighnibh Leinster-people (etc.) or the Gáedhel Gaels. Instead the English administrators and justices reduced the various peoples of Ireland to two groups, Hibernici (most Gaelic peoples) and Ostmanni (most Ost people), or occasionally referred to family names (such as the Oconughors [Ui Chonchobhair]). The exceptions were the Cineál Chonaill ('Kenelcunill') and Cineál Eoghain ('Keneleon'). Some Anglo-Irish, Welsh, and Ost people, however, were labelled Hibernici. The language of medieval 'colonialism' should not be repeated uncritically by historians. For more on this, see Hewer, 'Justice for all', 9-16.

${ }^{84}$ See John Morice vs Benedict son of John, below, 23.

${ }^{85}$ For example, William le Teynturner (1295) and Adam Benet (1297): CJRI, 1295-1303, $14,59,122-3$. There are several, later criminal cases which use the phrase 'Hibernicus et non de libero sanguine', but civil and criminal cases had different procedures. John Davies noted that a civil case from $c .1300$ used the phrase 'est Hibernicus, et non de libero sanguine': Davies, Discovery, 127, n. 183.

${ }^{86} \mathrm{ACN}, \mathrm{RC} 7 / 3,450$; below, case 1 .
} 
licitum est portare brevia in curia regis). ${ }^{87}$ The Dublin Bench ordered for a jury to be made to determine the case. Nothing else was recorded (in the surviving calendar) and this is important because some historians have mistaken pleas for court judgments and then presented the former as concrete legal facts. ${ }^{88}$ Henry and Margery, it seems, had created an original plea. There is no corroborating evidence that the jury or the justices of the Dublin Bench accepted this plea as legal fact. The fact that a jury was summoned to determine it may mean that the court considered it plausible, but there may have been further pleading which the nineteenth-century calenderer did not record. There are surviving records from the years immediately before when Gaelic people sued and were sued in the royal courts in Ireland and no mention was ever made of 'five lineages' ${ }^{9}{ }^{89}$ Henry and Margery do not name who these five lineages were, cite a recent statute or mandate which created this plea, or even tell us Mabel's surname. It may not have worked; Mabel could have been English, but we will probably never know.

The next surviving instance in which the plea was used occurred three years later in 1298, again in the Dublin Bench. John de Staunton and Joan Magelaghy [Iníon Mhic Ghiolla Eachaidh?], his wife, sued William de Bermingham, archbishop of Tuam, for two-thirds of the manor of Aghagower, Co. Connacht, of which he had disseised Joan's brother Matthew who had died and whose heir she was. ${ }^{90}$ The archbishop pleaded that Joan was a Hibernica and not of the five Gaelic lineages who were allowed to use English law (quinque progeniebus Hibernicis quibus licitum est uti lege Anglicana). This was a significant change in the plea. De Bermingham was not simply claiming that Hibernici could not bring a writ in the royal courts; he was claiming that they could not use any of the English courts in Ireland. ${ }^{91}$ Joan and John then countered the plea with the charge that the archbishop had to respond to the writ because although Joan was a Hibernica, she was the rightful heir of Benyach MacGreathey [Baethghalach Mag Oireachtaigh?] who had been enfeoffed by William's predecessor, Marian [Maolmhuire Ó Lachtáin (1236-49)], ${ }^{92}$ with the assent of the chapter of Tuam. This matches other cases when a defendant used est Hibernical-us plea, and the plaintiff countered that she/he had been enfeoffed and therefore was answerable

\footnotetext{
${ }^{87}$ Someone unable to bring a writ could possibly still 'use' the royal courts in others ways, such as answering a writ (defending her/himself).

${ }^{88}$ G.J. Hand, English law in Ireland, 1290-1324 (Cambridge, 1967), 198-210; Robin Frame, 'War and peace in the medieval lordship of Ireland', in J.F. Lydon (ed.), The English in medieval Ireland (Dublin, 1984), 118-41: 137-8.

${ }^{89}$ Hewer, 'Justice for all', 43-55.

${ }^{90} \mathrm{ACN}, \mathrm{RC} 7 / 5,413-14$; below, case 2 . At the time Connacht was a single county.

${ }^{91}$ The phrase could also much wider implications than simply using courts (use of currency, etc.).

${ }^{92}$ All dates of archbishops' reigns from: F.J. Byrne, 'Bishops, 1111-1534', in T.W. Moody, F.X. Martin and F.J. Byrne (eds), A new history of Ireland: vol. ix, maps, genealogies, lists (Oxford, 1984), 264-332: 319.
} 
in court. ${ }^{93}$ Joan and John continued their counterplea. After Benyach's death his son and heir, Adam, was taken into the king's hand because he was underage and the archbishopric was vacant. After Thomas Okenwor [Tommaltach Ó Conchobhair (1258-79)] was created archbishop of Tuam, he took homage from Adam son of Benyach and placed the latter in full seisin. Adam's son Matthew, after reaching full-age, gave homage to Stephen de Fulbourne, archbishop of Tuam (1286-8), and gave suit at Stephen's court. After Matthew died Joan Magelaghy claimed the inheritance as sister and heir of Matthew. De Bermingham then asked for proof of the original enfeoffment, and John and Joan stated that their charters had been destroyed in a fire at Athlithan and they wanted a jury to verify the original enfeoffment of Benyach MacGreathey (hoc parati sunt verificare). The archbishop then stated that the couple could not 'touch' this verification because Joan was a Hibernica. De Bermingham did not want the couple to be allowed to ask a jury to prove (or disprove) Joan's claim of the original grant. The parties were then given a day to hear the judgment, but no record of it survives. Joan's case is even more exceptional because she admitted to being a Hibernica. In most other cases when the est Hibernical-us plea was used, the plaintiff turned out to be legally English. ${ }^{94}$ The fact that the pleading continued in this case may demonstrate that the judgment would not be based entirely on the est Hibernica plea. In some cases the jury ignored the plea entirely. ${ }^{95}$

The third case was from the custos's court in 1313 (a custos was a temporary justiciar). Dionisia widow of John de la Ryvere complained by bill to the custos that Roger son of William detained 100s. which he owed her. ${ }^{96}$ She asked for the 100s. and damages. Roger appeared and pleaded that he was not bound to answer because Dionisia was a Hibernica and not one of the 'five bloods'. This is the first recorded instance of the term the 'five bloods' in the surviving court records. ${ }^{97}$ Roger son of William, just as Archbishop William and Henry Fulley and Margery, did not explain by what right (royal mandate, custom, etc.) he could use this plea. Roger then asked for an inquiry to be made by the county of Dublin. Dionisia said she was English and asked for the same. The jurors said that Dionisia was English and the court gave her judgment entirely on the plea. The jury made no report on the validity of the debt. But, interestingly, she received no damages and Roger was only amerced and not gaoled..$^{98}$

\footnotetext{
${ }^{93}$ See Hugh son of William's case in the justiciar's court: CJRI, 1295-1303, 336-7.

${ }_{94}$ Hewer, 'Justice for all', 88-9.

${ }^{95}$ CJRI, 1295-1303, 336-7.

${ }^{96} \mathrm{ACN}, \mathrm{KB} 1 / 1$, rot. 68r; below, case 3.

${ }^{97}$ The record of the putative 1309 case is not complete, but is mentioned below, 22-3.

${ }^{98}$ Because the justiciar's court gaoled one man who made the est Hibernicus plea, Geoffrey Hand believed that all royal courts in Ireland deemed the plea peremptory and odiosa. This conclusion is problematic because, as Hand admitted, the courts only gaoled one defendant and usually amerced the defendant for a false claim: Hand, English
} 
In 1331 twenty-two ordinances supposedly from a Westminster parliament were sent to be observed in Ireland..$^{99}$ The English parliaments were almost always informed of local politics and customs in English Ireland by petitions. These petitions were necessarily hyperbolic, but not entirely fictional. Some of the fourteenth-century statutes and ordinances sent from England were intended to ease conflict between Gaelic people 'at peace' and the settlers. One of these ordinances has been labelled 'una et eadem lex', and it has been used to claim that all betaghs were 'villeins'. ${ }^{100}$ The surviving calendar states: 'Item quod una et eadem lex fiat tam Hibernicis quam Anglicis excepta servitute betagiorum penes dominos suos eodem modo quo usitatum est in Anglia de villanis (also, that one and the same law be made for [all of] the Gaels as well as the English [of Ireland] except for the servile condition of the betaghs [who remain under] the power of their lords in the same manner as villeins in England)'. ${ }^{101}$ The government in England had learned that some people in Ireland wanted to deny all of the free Gaels access to the English courts in Ireland. This ordinance did not manumit the unfree; it does not prove that all Gaels were denied access to the royal courts; and it demonstrates that legislation is not always representative of 'the law'. It is well known that Gaels had to purchase grants of access to the courts in Ireland centuries after this ordinance, including some of the 'five bloods'. ${ }^{102}$ The 'good old customs' in English Ireland on many occasions overruled English royal mandates.

The fourth court case was heard two years after the ordinance 'una et eadem lex', but the pleading hinged on the plaintiff having been a Hibernicus and the disseisin happening before 1331. Richard son of Robert le Croucher brought an assize of novel disseisin against Alice Fubeley, Hugh son of Richard Tyrel, Nicholas son of Bertram Abbot and John son of Nicholas Abbot for one messuage (house with a small garden) and fourteen acres of land in 'Mestaillestoun' [Westpalstown?], Co. Dublin. ${ }^{103}$ Alice and Hugh, through their bailiff Nicholas,

law, 200. The gaoling in the one case was not because of the est Hibernicus plea, but instead because of the odiosa verdict by the court: Hewer, 'Justice for all', 89, 171-2.

${ }^{99}$ H.F. Berry (ed.), Statutes and ordinances, and acts of the Parliament of Ireland: King John to Henry V (Stat. Ire., John-Hen. V) (Dublin, 1907), 322-9. Berry's statute book claims that the ordinances were received at the Dublin exchequer in Michaelmas term, 5 Edward III, but the record of the parliament at Westminster on 30 September 1331 does not mention any of the supposed ordinances: PROME, Edward III, September 1331 (http://sd-editions.com/AnaServer?PROME+238452+text.anv+showall=1) $\quad(10$ Nov. 2017).

${ }^{100}$ Stat. Ire., John-Hen. V, 324-5; Bryan Murphy, 'The status of the native Irish after 1331', The Irish Jurist 2 (1967), 116-28; Hand, English law, 210.

${ }^{101}$ Stat. Ire., John-Hen. V, 324. Betaghs were a type of tenant who owed labour services. They have been confused with nativi (legally unfree people), but not all were. For more, see Hewer, 'Justice for all', 24-36.

${ }^{102}$ Davies, Discovery, 127; Murphy, 'Status'.

${ }^{103}$ ACN, RC 8/17, 150-2; below, case 4. Many thanks to Paul Brand for noting the place name. 
said nothing against the assize. Nicholas and John appeared and pleaded that the tenement was one messuage, six acres of land, one acre of meadow and one acre of moor. Then Nicholas claimed, as tenant of the one acre of moor, that Richard was a Hibernicus and not of free blood of the five bloods, and that Richard was not entitled to be answered in a royal court before the 'statute'. Nicholas had furthered the plea by claiming that all Hibernici were unfree except the 'five bloods'. We have many cases which prove that that was not true. ${ }^{104}$ Not only were there many free Gaels, but also most of them could use the English royal courts without a royal grant of access. John son of Nicholas claimed, as tenant of the rest of the tenement, the exact same plea as Nicholas. They prayed for judgment as to whether Richard had acquired the tenement after the 'statute'. They wished that the legislation did not have any retrospective element. ${ }^{105}$ Richard then counterpleaded that his grandfather was born in Wales, he himself was Welsh, of the Welsh gens, he was free, and not a Hibernicus. Nicholas and John repeated that Richard was a Hibernicus and not a Wallensis. The jury determined that Richard was a Wallensis and not a Hibernicus, and that he was in peaceful seisin of the tenement until Alice and Nicholas disseised him. The justices asked whether Hugh and John disseised him, and the jury said no. Then the justices asked whether the disseisin was made with vi et armis (force and arms), and the jury said yes. Being asked about damages, the jury said 50s. The justices then ordered that Richard recover seisin against Alice, Nicholas, and John by viewing of the recognitors with the $50 \mathrm{~s}$. in damages. The record does not explain how John was in possession but had not disseised Richard. Clearly, Alice and Nicholas had granted access to the tenement to John and he had partial possession of it at that time. Alice and Nicholas were held in custody until Nicholas made fine by $40 \mathrm{~d}$. This case investigated the plea but then determined the judgment based on the facts and the jury did not make the verdict simply on the est Hibernicus plea.

The fifth and final surviving case record which contains a 'five' plea is from 1354. A 'Gaelic' man claimed to be an Ó Néill 'of Ulster' and the jury agreed. ${ }^{106}$ Many historians have pointed to this record as concrete proof of a thirteenth-century royal grant (beginning with John Davies), but there are problems with the last record. Simon Neel sued William Newlagh for breaking the former's 'close' and William replied that Simon was a Hibernicus and not of the five bloods, and therefore should not be answered. ${ }^{107}$ This plea should have been overruled by the court as impertinent after the una et eadem lex ordinance.

\footnotetext{
${ }^{104}$ Hewer, 'Justice for all'.

${ }^{105}$ Paul Brand called this 'a very restricted interpretation of the statute'.

${ }^{106}$ Despite being called a Hibernicus, Simon Neel may have been English by blood (matrilineal) and custom or one of the English people with the surname 'Neel'. There is no corroborating evidence.

${ }^{107}$ BL, Add. MS 4790, ff 67v-68r [case no. 5 below]; Davies, Discovery, 126-7; J.S. Brewer and William Bullen (eds), Calendar of Carew Manuscripts preserved in the archiepiscopal library at Lambeth (London, 1871), 352.
} 
Simon counterpleaded that he was an Ó Néill of Ulster and through a grant from the progenitors of the king of England (then Edward III) the Uí Néill were able to use and enjoy English liberties and be regarded as free people, and he offered to verify this. Simon Neel had changed the exception of the 'five bloods' from a local custom (of attempting to deny free Gaels access to an English royal court in Ireland) to an English royal grant. The court then determined Simon was an Ó Néill of Ulster and he was awarded damages. The problems with this record are that the pleading does not prove the existence of any royal grant and Simon Neel was from Dublin. The property claimed in the suit was in Clondalkin, Co. Dublin, and a Simon Neel witnessed deeds made in the city of Dublin, concerning property in the city, eight years earlier (1346) and eight years later (1362). ${ }^{108}$ Based on his naming practices and acceptance in the city of Dublin, it appears that Simon was Anglicised, and was probably born in Dublin. None of the surviving copies of this court case reveal how the jury reached the decision that Simon was 'of Ulster'. He may have had friends on the jury, but there is no surviving record indicating that William Newlagh complained to the court or brought a writ of attaint (false verdict by the jury). In the fifteenth century several Uí Néill purchased access to the English courts. It would appear therefore that the judgment in Simon's case and the repeated claims that the 'five bloods' grant was real did not enfranchise all Uí Néill.

In each of the surviving five instances in which it was used, the wording of the plea changed variably. These instances were part of a larger trend to use, and even create, new pleas to deny various peoples access to redress from the courts. It appears that the defendants in the 'five lineages' and 'five bloods' cases were searching for the exact wording to convince the justices to rule on substantive law, and these defendants thought that the 'common law' denied access to all Hibernici except the five lineages/bloods, or at least that they could convince a jury of this narrative. It was not the 'common law' to deny any and all Gaelic people access to the English royal courts in Ireland. This 'five lineages' plea was an attempt to deny access to the courts to previously enfranchised people, which was not the same as bondage or universal unfranchisement (the state of never having been enfranchised). The conflation of the state of being a Hibernical-us, in this sense an Irish Gael, with being unfranchised appears to have been a consequence of Anglo-Gaelic relations over the 120 years since the advent of

\footnotetext{
${ }^{108}$ M.J. McEnery and Raymond Refaussé (eds), Christ Church Deeds (Dublin, 2001), nos 626, 631, 690, 692. A Simon Neel of Nellestone (Neel's town or, possibly, [Ó] Néill's town), Clondalkin bought lands near the archbishopric of Dublin's lands and was seized by the archbishop as a nativus in 1357. This is very peculiar because this same Simon was a citizen of Dublin and therefore could not be a nativus. This Simon's children and grandson appear to have been treated as free though: Charles McNeill (ed.), Calendar of Archbishop Alen's Register, c.1172-1534 (Dublin, 1950), 224, 236-7, 302. A 'jurat' of the city of Dublin in 1320 was a Simon Neel, perhaps the father of the Simon who witnessed the Christ Church deeds: J.T. Gilbert (ed.), Calendar of ancient records of Dublin (18 vols, Dublin, 1889-1922), vol. 1, 122-3.
} 
the English in Ireland and a deficiency of the collective legal memory of the Anglo-Irish society. What I mean by this is that some (but not most) juries in the fourteenth century commented that Hibernici were denied access to the courts and it appears this belief was a misunderstanding of the concept of Hibernici et nativi. It is also pertinent that the first three cases concerned women. The first two were married to Englishmen, but these men did not 'cover' their wives. It has been traditionally argued that 'coverture' (supposedly a complete lack of agency for married women) was in full and universal effect in high medieval English Ireland. ${ }^{109}$ Under 'coverture' wives should have been 'protected' by their husbands, but the court records demonstrate that husbands in interethnic marriages rarely 'covered' their wives in regard to legal ethnicity. The third case, a widow seeking recompense for a debt, is part of a clear trend to disseise single widows and that defendants were attempting to use the est Hibernical-us plea in personal actions as well as land cases. It — and the fourth case - also evinces the prevalence of false claims (pleas) by defendants in court against women and men plaintiffs as both plaintiffs were discovered to be not Gaelic.

There is one more record, but it too is rather problematic. In the Carew MSS there is an incomplete record of a 'case' from 1309 (3 Edward II). ${ }^{110}$ According to Carew, Philip de Monsterworth and Richard de Abbedley were attached to answer William O'Kelly [O Ceallaig] why they had attacked and imprisoned him contrary to the English king's letters of protection. Philip and Richard replied that they were not bound to answer William because he was a Hibernicus and not 'of the blood or progeny who enjoy the English law'. John Davies may have looked at the same original record, and he recorded the phrase as: 'qui gaudeant lege Anglicana quoad brevia portanda' (who enjoy English law as far as bringing writs). ${ }^{111} \mathrm{It}$ is interesting that the wording of this supposed plea combined the phraseology from the first, second, and third cases which may demonstrate that the defendants were eagerly searching for the 'right' wording to disenfranchise free Gaels. These defendants had combined the phrase 'lege Anglicana' (from case no. 2) with 'brevia portanda' (from case no. 1: portare brevia) which may indicate that the various defendants or their narratores ('pleaders': those who spoke before the justices in court) were colluding in this process. The Carew record then states that the Hibernici who could bring a writ were the Uí Néill of Ulster, Uí Chonchobhair of Connacht, Uí Bhriain of Thomond, Uí Mhaoilsheachlainn of Meath, and the Meic Mhurchadha of Leinster. ${ }^{12}$ The Carew MS does not call them the 'five bloods' or the 'five lineages', nor does it

\footnotetext{
${ }^{109}$ For the historiography and problems with this argument, see Hewer, 'Justice for all', $113-31$.

${ }^{110}$ Brewer and Bullen (eds), Calendar of Carew Manuscripts, 452-3.

${ }^{111}$ Davies, Discovery, 127.

${ }^{112}$ Compare the order of the names in the Carew MS with the order of the 'five' in Titus B XI: Onealo of Ulster, Obrien of Tomond, OMalaghlin of Medhe, OConnogher of Connaght, Obrien of Tomond, M $\mid c /$ Murogho of Leinster. John Davies listed them in the same order as Titus B XI.
} 
state that there was a royal grant to these families. The first problem with this record is that William O'Kelly was under a royal protection and that should have nullified the plea (of 'we do not have to respond'). The next problem is that this appears to be an appeal contra pacem regis which would also negate their plea. Assuming that Carew made this calendar from an actual court record from 1309 there are some interesting revelations. ${ }^{113}$ The phrase "not of the blood or progeny [progenies]' reveals the linguistic change form 'lineages [progenies]' to 'bloods [sanguines]'. Despite the fact the names are in a different order in the various MSS, it appears that the defendants in this attachment may have named the 'five'. If true, this demonstrates that the choice of the 'five' was by someone who was not part of the English administration in Ireland. As earlier discussed, the chancery, exchequer, and court records all confirm that Dublin (and the English crown) did not call or consider the Uí Néill kings 'of Ulster'. ${ }^{14}$

Three other contemporary cases elucidate some problems with framing English law in Ireland as codified and provide some context for the 'five lineages' cases. In 1297 John Morice complained to the justiciar that Benedict son of John de Drogheda had forestalled (an attack and robbery on a highway) Morice at Dundalk, Co. Louth, and would have killed Morice if he had not given Benedict his horse worth 10 marks (occidisse voluit nisi reddidisset equum suum). ${ }^{115}$ Benedict replied that Morice gave Benedict the horse freely to repay a debt. Morice countered this with the charge that Benedict was not allowed to plead in court because the latter was a Hibernicus and not admitted to use the 'free law' (i.e. access to the English royal courts). Benedict then presented letters patent of Edward I granting Benedict and his children the right to use English law in Ireland. John Morice later admitted that malefactors had stolen the horse and Benedict had rescued it from them. The justiciar pardoned Morice's amercement. No reason was given. Morice's plea indicates that he believed that no Hibernici could speak in court, but by suing Benedict, John Morice was alleging Benedict to have been free. Unfree people in England (and English Ireland) were not to be sued because answering a writ in a royal court could prove someone's freedom. ${ }^{116}$ Villeins in England could defeat a writ by claiming that they were villeins so that they did not have to (or could not) answer the writ. English lords

${ }^{113}$ This record is also peculiar because a William O'Kelly sued the prior of the house of St Michael of Duleek and Brother Richard of that house in 1306 for false imprisonment and destruction of O'Kelly's goods. This William claimed that the prior and Richard did this in revenge for William suing them, on behalf of Edward I of England, for violating the Statute of Mortmain. The jury did not agree, but William was allowed to prosecute his case in the justiciar's court (i.e. fully allowed to use English royal courts): Hewer, 'Justice for all', 78.

${ }^{114}$ See above, 6-7.

${ }^{115}$ ACN, RC 7/4, 259; CJRI, 1295-1303, 82.

${ }^{116}$ P.R. Hyams, King, lords and peasants in medieval England: the common law of villeinage in the twelfth and thirteenth centuries (Oxford, 1980), 145-55; Hewer, 'Justice for all', 24-36. 
were allowed to interfere in court cases involving their villeins to prevent any emancipation. ${ }^{117}$

In 1300 Hugh son of William brought an assize of novel disseisin against John Tebaud for half an acre of land and the profits of a mill in Co. Cork. ${ }^{118}$ Tebaud said that he was not obliged to answer because Hugh was a Hibernicus. Hugh said that did not bar him from access to the royal courts because his father, William, had enfeoffed him of the tenements and put him in full seisin (just as Joan Magelaghy claimed). Hugh son of William did not claim that he was a free man because that was not the issue. The problem was solely his supposed legal ethnicity. The jury returned that Hugh was never in seisin of the tenement, so he was amerced for false claim. They made no ruling on his status. He appears to have been free and accepted and allowed to use the royal courts. Hugh son of William's and John Morice's cases indicate that est Hibernicus/-a plea (without the proviso 'et non de quinque progeniebus') was not the determinant for court judgments (pleading continued and the verdict was based on the facts and not on the plea) and could be ignored by the courts at that time. Ignoring the plea is a good indication that it was not a rule of law.

After the 1331 ordinance 'una et eadem lex' was declared in Ireland, it was cited by a plaintiff and a defendant in regard to a 'bill' (querela: oral complaint instead of a chancery writ), and this pleading also reveals an aspect of legal acceptance. Walter Ultagh [Ultach] sued Thomas de Penkester for $10 \mathrm{~s}$. of silver, and the latter replied he would not respond quia est Hibernicus (because he is a Gael). Ultagh counterpleaded that in a parliament it had been decreed that omnes Hibernici ad pacem regis existentes respondetur ad commune legem $\& c$ et dicit quod ipse ad pacem domini regis ('all Hibernici at peace are to be responded to in court, and he [Walter Ultagh] was at peace'). ${ }^{119}$ De Penkester responded that the contract for the $10 \mathrm{~s}$. had been made before the summoning of that parliament (similarly to the defendants in Richard son of Robert's case, Thomas wished to deny any retroactive enforcement), but the court agreed with Ultagh and granted him the $10 \mathrm{~s}$. and damages. Ultagh then waived the damages as a successful plaintiff. Ultagh's claim, and the court's acceptance of it, may explicate how so many Gaels without grants of access to the English courts were allowed to use the royal courts. As long as free Gaels living in English Ireland were not 'rebelling' or committing felonies they were allowed to use the English royal courts in Ireland just as the English and Welsh were allowed to do. ${ }^{120}$

\footnotetext{
${ }^{117}$ Hyams, Kings, lords, 145-6.

${ }_{118}$ CJRI, 1295-1303, 336-7.

${ }^{119} \mathrm{ACN}, \mathrm{M} 2542$, 204. This record is one of William Betham's notebooks. It does not give us the entire record, the date, or the specific court. It even switches from Latin to English in the middle of the record. But other historians have cited it as reliable.

${ }^{120}$ For Scots in English Ireland, see S.G. Hewer, 'Scots in "English Ireland" in the thirteenth and fourteenth centuries', Scottish Historical Review 97 (245) (Oct., 2018), 211-17.
} 
Assessing the strength of the claim
The choice of the 'five bloods' in the surviving records were clearly made by someone who was not familiar with Irish politics and interethnic relations in 1218 or 1309. Between the dates of the two 'grants' there are many indications that the five families were not considered 'English' people and did not 'enjoy' English law. Some of the relations between these groups and the crown of England have been analysed, but usually in relative isolation. ${ }^{121}$ There were remarkable similarities among the five families and the treatment of other Gaelic royal families provide pertinent context for the supposed grants. ${ }^{122}$ Some of the five were given English royal charters for their lands, but then these charters were declared null and void for 'rebellions'. Subsequently, these kings lost large portions of, or almost all of, their lands. The English magnates in Ireland prevented royal heirs from inheriting lands and titles, and the former assisted rivals in taking the kingships by force. On the other hand, there were many Gaelic families who were 'enfranchised' (accepted as free members of English Ireland, allowed to own lands in fee, and could sue in the English royal courts). The evidence of free Gaels using the English royal courts without any grant of access disabuses us of the assumption that the 'five bloods' plea proves a legal rule of absolute legal discrimination against all Gaels. The records of free Gaels winning court cases and the problems with the surviving records may indicate the origins of the claims in the Cottonian notes. The defendants in the royal courts who wished to disenfranchise free and accepted Gaels in English Ireland tried out various pleas and repeated them outside of court in an attempt to create 'good old customs'.

The fact that the defendants who invented the 'five lineages' plea decided that the number of Gaels allowed to use the English courts in Ireland should have been five may have had some remote connection to the cuiigidh (fifths of Ireland) and the cuiigeadhaig (kings of the fifths). There are, however, problems with this theory. The note in MS Titus B XI claims that the 'five' were the kings of Ultonia, Mide, Connacht, Thomond and Laighin, but Thomond should instead be Mumu (Munster) of which Thomond was only the northern portion. The southern portion was Desmond and its kings, the Meic Charthaigh, are noticeably absent from the 'five bloods' records. The Meic Mhurchadha did not have control of Laighin in 1218 or 1309. The Uí Néill did not control, or even claim to be in, Ultonia in 1218. And the Uí Mhaoilsheachlainn were not a major interprovincial power in the midlands despite being kings of Mide. If it is the case that the supposed grant was simply invented, its fabricator was presumably

\footnotetext{
${ }^{121}$ Walton, 'English in Connacht'; Robin Frame, 'The justiciar and the murder of the MacMurroughs in 1282', in idem, Ireland and Britain, 1170-1450 (London, 1998), 241-8; Aoife Nic Ghiollamhaith, 'Kings and vassals in later medieval Ireland: the Uí Bhriain and the MicConmara in the fourteenth century', in Barry et al., Colony and frontier in medieval Ireland, 201-16; Verstraten, 'King and vassal'. Emmett O'Byrne examined the Meic Mhurchadha and Uí Chonchobhair and occasionally the Uí Bhriain and Uí Néill: O'Byrne, War, politics and the Irish.

${ }^{122}$ Goddard Orpen also noticed the similar treatment of Gaelic kings by the crown of England: Orpen, Ireland under the Normans, 461.
} 
English and anti-Gaelic, and hence the unfamiliarity with Gaelic kings and kingdoms is understandable. It seems more probable that the 'five' were based on Gerald of Wales's mythical 'five divisions' to be conquered by a sixth predicted by Merlin Ambrosius. ${ }^{123}$ Gerald's Expugnatio Hibernica was popular in English Ireland and many of his unsubstantiated claims were repeated uncritically for centuries.

The charters given by King John of England to Cathal Croibhdhearg Ó Conchobhair and the Uí Bhriain of Thomond did not manumit them. These families were already free. They were kings. As is well known these charters did not make these kings, or their descendants, magnates in English Ireland with guaranteed rights to inherit their lands and titles in primogeniture. ${ }^{124}$ We have already learned that Conchobhar Ó Briain was explicitly told that he could not inherit his ancestral lands without paying a fine of 2,200 marks after his father, Donnchadh Cairbreach, had held the same lands in fee by charter. This fine would only allow Ó Briain to hold the lands at 'pleasure' (without any guaranty). Conchobhar eventually negotiated a lease of his own lands (c.1253), but then complained to Henry III of England that royal bailiffs harassed the former by summoning him to court in Limerick. ${ }^{125}$ At the same time Henry III was granting cantreds (vast areas of land) in Ó Briain territory to Englishmen to take by force. ${ }^{126}$ Access to the English courts for the Uí Bhriain, Uí Chonchobhair, and Uí Néill did not bring legal protection from invasion or worse. ${ }^{127}$ As noted above, by 1235 the Uí Chonchobhair had been deposed in Co. Connacht and had been reduced to holding part of Co. Roscommon (or 'the king's cantreds') at 'pleasure'. ${ }^{128}$ During the next forty years the Ó Conchobhair lands were diminished from five cantreds to two.

Between 1210 and 1260 the Uí Néill gained power in Tír Eoghain. They ended any Mac Lochlainn threat and then formed an alliance against the Uí Dhomhnaill. ${ }^{129}$ During the second escheat of Ulster in the thirteenth century (1243-63) the Irish exchequer occasionally recorded the rent owed by the Uí Néill for 'Cineál Eoghain' (instead of Tír Eoghain) under the accounts for Ulster. ${ }^{130}$ But at the same time the crown of England was demanding aids directly from the Uí Néill for the king of England's wars in Wales (1251-2) and Gascony (1253-4)

\footnotetext{
${ }^{123}$ Giraldus Cambrensis, Expugnatio Hibernica: the conquest of Ireland, ed. A.B. Scott and F.X. Martin (Dublin, 1978), 96-7.

${ }^{124}$ Walton, 'English in Connacht', 45; Verstraten, 'King and vassal', 14; Robin Frame, 'England and Ireland, 1171-1399' in idem, Ireland and Britain, 15-30: 20-4.

${ }^{125}$ Cal. Docs Ire., vol. 2, nos 272-3.

${ }^{126}$ Orpen, Ireland under the Normans, 464-6.

${ }^{127}$ There are no surviving cases of the Uí Mhaoilsheachlainn using the English royal courts in Ireland in the thirteenth century.

${ }^{128}$ Orpen, Ireland under the Normans, 361-94; Walton, 'English in Connacht', 63-82; Verstraten, 'King and vassal', 14-20.

${ }^{129}$ Simms, 'O Hanlons', 76-8.

${ }^{130}$ Gilbert (ed.), Facsimiles, vol. 2, plate 73.
} 
and occasionally recorded rent owed from the Uí Néill as being independent of Ulster. ${ }^{131}$ On the other hand, in 1269 Aodh Buidhe Ó Néill acknowledged that he held his kingship (regalitas) from Walter de Burgh, count of Ulster (cont d'Uluestre). ${ }^{132}$ The Uí Néill were consistently going to war against the English and Gaels in the north. Domhnall Ó Néill took the kingship of Tír Eoghain c.1283, but was deposed by Richard de Burgh and the justiciar in $c .1286 .{ }^{133}$ Ó Néill recovered the kingship in 1295, and famously joined the Bruce invasion in 1315. ${ }^{134}$

The five families chosen are revealing. Several of them complained to the crown of England that local, royal bailiffs summoned the former to court. The five did not sue Englishmen for invading their lands nor attend an English parliament after the crown disseised the former of their ancestral lands. When English settlers from Meath invaded Connacht in 1218 the Uí Chonchobhair reacted by knocking down an English castle. The Uí Néill temporarily allied with the various counts of Ulster, tried to invade Down, and then assisted the Bruce invasion of Ireland. In 1258 Brian Ó Néill, Aodh Ó Conchobhair, and Tadhg Ó Briain met at Caol Uisce in Fir Manach and offered Ó Néill the 'kingship of the Gaels of Ireland'. All three had recently lost lands or been defeated by rival Gaels or English armies. Modern historians have attached significant gravitas to this event, but Aodh was not king of Connacht, Tadhg was not king of Thomond, and no other Gaelic king recognised Ó Néill as high king. In fact just before the 'inauguration' at Caol Uisce, a dying Goffraid Ó Domhnaill rallied his men to defeat Brian Ó Néill at Loch Súilí. ${ }^{135}$ In 1260 Brian Ó Néill and Aodh Ó Conchobhair were defeated at the Battle of Down by local men (possibly with help from Gaels). Ó Conchobhair escaped, but Ó Néill was beheaded. These events have been labelled the beginning of 'the Gaelic Resurgence' (or other similar names). ${ }^{136}$ Recently some scholars have argued that the idea of a united Gaelic resistance is anachronistic and belies the fact that the movement was equally about fighting other Gaelic groups as it was about fighting the English. ${ }^{137}$ But clearly the English government in Ireland and the crown of England were not inclined to grant privileges to these three families at that time, and the latter were likewise antipathetic to asking for such a grant.

\footnotetext{
${ }^{131}$ Simms, 'O Hanlons', 81; Davies and Quinn, 'Irish pipe roll', 36-7 (Meath), 66-7 (Uriel). ${ }^{132}$ Report on the manuscripts of Lord De L'Isle and Dudley (6 vols, London, 1925-66), vol. 1, 31-2.

${ }^{133}$ Simms, 'O Hanlons', 87-8.

${ }^{134}$ Seán Duffy (ed.), Robert the Bruce’s Irish wars: the invasions of Ireland 1306-1329 (Stroud, 2001).

${ }^{135}$ Orpen, Ireland under the Normans, 417-18.

${ }^{136}$ For 'Gaelic Resurgence' see Lydon, 'Land of war', 240-74; for 'Irish Revival', see Edmund Curtis, A history of medieval Ireland from 1086 to 1513 (2nd ed., London, 1938), 245-9, 419-24; for 'Irish Rally', see Eoin MacNeill, Phases of Irish history (reprint, Dublin, 1968), 323-56.

${ }^{137}$ O’Byrne, War, politics and the Irish of Leinster, 63.
} 


\section{Conclusion}

The earliest instances in which the 'five lineages' plea was used do not evince any royal grant and Simon Neel's case only demonstrates that one jury thought that Simon Neel should win his court case. There are no surviving English royal letters to the five families from the thirteenth century calling them the 'five lineages' (or 'five bloods'). There are no records of debts owed by these families for their 'enfranchisement'. It appears most likely that the supposed grant from 1309 is an early modern miscopy of a defensive plea and that the supposedly earlier grant (from 1218) may be a forgery or a misdated copy of the 1309 pleading. Since both 'notes' in Cotton MS Titus B XI claim to be grants, they might well be termed forgeries. The 'five lineages' plea first appears (in our admittedly very meagre records) in 1295 and the 'five bloods' plea first appears in $c .1309$. Since the supposed grant in 1218 was to the 'five bloods', then the forgery must have been made after 1309. The choice of the five is important. Four of the five kings over the thirteenth century lost vast amounts of land and power at the hands of rivals and English settlers (though the Uí Néill seem to have increased their power at that time). The Uí Néill, Uí Chonchobhair, and Uí Bhriain occasionally fought the English settlers in their regions and in other regions. Four of the five (excluding the Meic Mhurchadha) were not inclined to sue in the English courts. Most of their lands were outside 'English Ireland'. It appears from the extreme variation in the pleading that it was the disparate defendants who decided that the 'five' should be the Uí Néill of Ultonia, the Uí Mhaoilsheachlainn of Mide, the Uí Chonchobhair of Connacht, the Uí Bhriain of Thomond, and the Meic Mhurchadha of Laighin. It was not a justiciar or the crown of England. This theory would explain the incongruity with the political situation in 1218 and 1309.

There are also the two, very large problems of other Gaelic kings who were recognised by the English administration and free Gaelic commoners who could use the English royal courts in Ireland. The 'five lineages' plea was a clear attempt to deny access to the English courts to all of the free Gaels living within the English lands in Ireland. The making of these supposed grants was not an isolated incident. The English law in Ireland had numerous, invented 'traditions'. ${ }^{138}$ It was customary to concoct false histories to placate later political situations and cultural shifts, but even with these forgeries and fictional histories the English royal courts in Ireland did not exclude every single free Gaelic person in the thirteenth or early fourteenth centuries. Common belief in a fictional history

\footnotetext{
${ }^{138}$ For the Statute of Henry fitz Empress (1460), see H.G. Richardson and G.O. Sayles, The Irish Parliament in the Middle Ages (Philadelphia, 1952), 324-5; Art Cosgrove, 'Parliament and the Anglo-Irish community: the Declaration of 1460', in Art Cosgrove and J.I. McGuire (eds), Parliament and Community (Belfast, 1983), 25-41; Peter Crooks, "Representation and dissent: "Parliamentarianism" and the structure of politics in colonial Ireland, $c .1370-1420$ ', English Historical Review 125 (512) (2010), 1-34: 28-9. Cf. the supposed papal grant Laudabiliter: Anne Duggan, 'The power of documents: the curious case of Laudabiliter', in Brenda Bolton and Christine Meek (eds), Aspects of Power and Authority in the Middle Ages (Turnhout, 2007), 251-75.
} 
did not, and does not today, actualise the putative royal grants. The custom, however, of repeating the invented history does appear to have turned the narrative - that only 'five bloods' could use the royal courts - into a regional legal custom in the mid-fourteenth century within the larger 'common law' tradition. But as with most customs, it was not universally observed or enforced.

The 'five bloods' was, it appears, just a claim in court, which in the surviving records never worked (i.e. quashed the writ). So far as we can tell, no English king in the thirteenth or early fourteenth centuries recognised the 'five bloods' or demanded payment for their supposed enfranchisement. Perhaps, therefore, the grant to the 'five bloods' only appears real now because seventeenth-century men (Davies and the Cottonian clerk) confused a defensive plea in 1309 for a royal grant and the Cottonian clerk uncritically repeated - or created - a forgery with no corroborating royal confirmation. As Paul Brand has effectively shown, John Davies is not a reliable source for the substantive law in English Ireland (medieval or early modern). ${ }^{139}$ The 'five bloods' plea was a pretence fabricated in order to disenfranchise customarily free Gaels in English Ireland and it did not work.

Acknowledgements Many thanks to Paul Brand, Peter Crooks and Seán Duffy for reading draft versions of this paper and providing numerous, valuable comments. Any remaining mistakes are entirely my own.

${ }^{139}$ Paul Brand, 'Sir John Davies: law reporter or self-publicist?', The Irish Jurist 43 (2008), 1-20. 
Appendix: the court cases with 'five lineages' and 'five bloods' pleas $^{140}$

\section{Case of dower from the Dublin Bench, Michaelmas term, 23 Edward I [1295].}

ACN, RC 7/3, 450: [Dublin'] Willelmus Auncel \& Mabila uxor ejus petunt versus Henricum Fulley \& Margeriam uxor ejus 1/3 partem 20 acrarum ut dotem ipsius Mabile que eam contingit de libero tenemento Johannis de Balingford quondam viri sui in Correston'; dicti Henricus \& Margeria dicunt quod non tenentur eisdem Willelmo \& Mabile inde ad hoc breve respondere quia dicunt quod dicta Mabila est Hibernica \& non de 5 progeniebus Hibernicis quibus licitum est portare brevia in curia regis; fiat jurata \&c.

2. In this case, the plaintiff, Joan, admits to being a 'Hibernica'. It is from the Dublin Bench, Michaelmas term, 26 Edward I [1298]. The surviving calendar has numerous cross-outs and superscript additions and it is not possible to tell which are recording medieval cancellations and interlineations and which are nineteenthcentury edits by the clerk [Robert Maguire] or by the Record Commission superintendent [Richard Sleater]. Repetitions which were cancelled have been left out of this transcript.

ACN, RC 7/5, 413-14: [Connacia] Johannes de Staunton \& Johanna uxor ejus petunt versus Willelmum archiepiscopum Thuamensis 2 partes manerii de Anchethawyr ut jus et hereditatem ipsius Johanne et de quibus idem archiepiscopus dissesivit Mathaeum Magelaghy fratrem ipsius Johanne cujus heres ipsa est; dictus archiepiscopus dicit quod non tenetur respondere quia dicta Johanna Hibernica est et non de 5 progeniebus Hibernicis quibus licitum est uti lege Anglicana; dicti Johannes et Johanna $\backslash_{\text {uxor ejus }} /$ dicunt quod \dictus archiepiscopus/ tenetur licet lipsa/ Johanna Hibernica sit eo quod quidam Marianus archiepiscopus Tuamensis predecessor Idicti/ Willelmi feoffavit Benyach Macgreathey de dictis 2 partibus de assensu capituli sui et post mortem lejusdem/ Benyach Adam filius \& heres ejus infra etatem existens fuit in custodia regis sede Tuamensis tunc vacante et postmodom Thomas Okenewor creatus fuit [archiepiscopus] ${ }^{141}$ Tuamensis et \quia dictus/ Adam plene etatis fuit idem Thomas cepit homagium ipsius ejus Ade pro eisdem partibus et post mor-

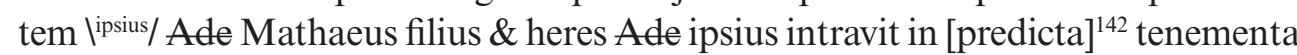
et $\backslash^{\text {quia idem/ }}$ [Mathaeus fuit] ${ }^{143}$ infra etatem fuit in custodia Stephani de Foleburne tunc archiepiscopi Tuam ([qui quidem]/144 Mathaeus postquam fuit plene etatis fecit

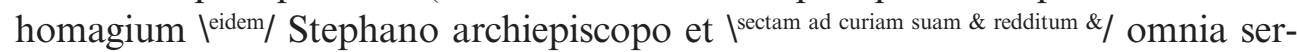
vicia debita de eodem tenementi dicto Willelmo archiepiscopo successori lejusdem/ Stephani) cujus Mathaei dicta Johanna heres est; dictus Willelmus archiepiscopus

\footnotetext{
${ }^{140}$ Many thanks to Paul Brand for his numerous comments on my transcriptions of these cases.

${ }^{141}$ episcopus in MS.

142 predicta in MS.

${ }^{143}$ Mathaeus qui fuit in MS.

${ }^{144}$ quiquidem in MS.
} 
petit quid habeant de feoffamento inde facto dicto Benyath per Marianum archiepiscopum; dicti Johannes \& Johanna dicunt quod carta combusta fuit apud Athlithan \& hoc parati sunt verificare; dictus Willelmus archiepiscopus dicit quod non possunt attingere ad predictam verificacionem in hoc casu cum dicta Johanna sit Hibernica; dies datus est de judicio suo audiendum.

3. The third surviving case is from the custos's court on 17 June 6 Edward II [1313]. In this case the plea had changed from 'five lineages' to 'five bloods'. This is the oldest (surviving) case which uses that phrase. In this case, the plea decided the verdict. The court did not confirm or deny the alleged debt. It is also important because the court did not award any damages. ${ }^{145}$

ACN, KB 1/1, rot. 68r: Placita querelarum apud Dubliniam coram Edmundo le Botiller custode terre Hibernie in octabis sancte Trinitatis anno regni regis Edwardi filii Edwardi sexto. Botiller..

[Dublin'] Dionisia que fuit uxor Johannis de la Ryvere queritur de Rogero filio Willelmi eo quod iniuste detinet centum solidos argenti quos ei debet etc. sicut rationabiliter monstrare poterit letc. et non dum etc./ ad grave dampnum ipsius Dionisie. Et inde petit remedium etc.

Et predictus Rogerus venit et dicit quod non tenetur ei inde respondere. quia dicit quod predicta Dionisia Hibernica est et non de quinque sanguinibus etc. Et hoc petit quod inquiratur per patriam. Et predicta Dionisia dicit quod Anglica est. Et hoc petit similiter quod inquiratur per patriam. Ideo fiat inde jurata Et Henricus le Blount, Robertus Locard, Johannes filius Michaelis de Kyllegh', Willelmus de Uriel, Willelmus Bek', Ricardus Portreve de Grenok', Johannes Rosel, Johannes Clericus, David Haye, Willelmus Iosep, Johannes Drake, et Henricus Chorle juratores dicunt super sacramentum suum quod predicta Dionisia Anglica est. Ideo consideratum est quod predicta Dionisia recuperet versus predictum Rogerum predictos centum solidos. Et Rogerus in misericordia.

4. The fourth case occurred after the ordinance 'una et eadem lex'. In this case the 'five bloods' plea did not determine the verdict. After it was determined not to be true, the facts of the case were decided. The plaintiff, Richard, was awarded damages and his is the oldest surviving case in which the plea was used against a man. The case is from the Dublin Bench, Michaelmas term, 6 Edward III [1332].

ACN, RC 8/17, 150-2: [Dublin'] Assisa venit recognitura si Alicia ffubeley, Hugo filius Ricardi Tyrel, Nicholaus filius Bertrami Abbot', et Johannes filius

${ }^{145}$ Many thanks to Zoë Reid, senior conservator at ACN, for giving me access to the original court roll. 
Nicholai Abbot' injuste disseisiverunt Ricardum filium Roberti le Croucher de libero tenemento suo in Mestailleston' unde queritur quod disseisiverunt eum de uno mesuagio et 14 acris terre in eadem villa; et predicta Alicia per Nicholaum Abbot' tanquam ballivum suum et predictus Hugo per predictum Nicholaum tanquam ballivum suum, veniunt et nichil dicunt quare assisa versus eos capi non debeat, ideo versus eos capiatur assisa; et predicti Nicholaus et Johannes veniunt et dicunt quod tenementa posita in visu non sunt nisi unum mesuagium, 6 acre terre, una acra prati, et una acra more, et predictus Nicholaus ut tenens de predicta acra more dicit quod predictus Ricardus est Hibernicus et non de libero sanguine de quinque sanguinibus et inhabilis responderi ante statutum, et predictus Johannes ut tenens de predictis mesuagio 6 acris terre et una acra prati dicit similiter quod predictus Ricardus est Hibernicus etc., et petunt judicium si assisa inter eos debeat nisi ostendat titulum quomodo liberum tenementum ei accrevit post statutum. Et predictus Ricardus dicit quod avus suum natus fuit in Wallia et quod ipse est Walensis et de genere Walensium et sic est liber et non Hibernicus. Et predicti Nicholaus et Johannes dicunt quod predictus Ricardus est Hibernicus et non Walensis; ideo capiatur jurata que remansit capienda usque in crastino animarum pro defectu juratorum. Postea partes veniunt hic et juratores qui dicunt super sacramentum suum quod predictus Ricardus Walensis est et non Hibernicus et quod predictus Ricardus pacifice seisitus fuit de predictis tenementis quousque predicti Alicia et Nicholaus ipsum inde disseisiverunt. [Et juratores] requisiti si predicti Hugo et Johannes ipsum disseisiverunt necne, dicunt quod non; requisiti si disseisina facta fuit vi et armis necne, dicunt quod sic; requisiti [eciam] de dampnis, dicunt 50s. Ideo consideratum est quod predictus Ricardus recuperet seisinam suam de predictis tenementis versus predictos Aliciam, Nicholaum, et Johannem per visum recognitorum assise predicte cum dampnis suis taxatis per predictam assisam ad 50 s., et predictus Ricardus in misericordia pro falso clamore, et predicti Alicia et Nicholaus capiantur \&c. Postea predictus Nicholaus venit hic et fecit finem regi per $40 \mathrm{~d}$.

5. The only other case involving the plea survives in a seventeenth-century calendar (Codex Clarendon, vol. 43 [ante 1624]) and is written in an early modern script. The case was supposedly from 28 Edward III [1354], but the surviving record does not specify where the case was heard (Dublin Bench, justiciar's court, or other) or even which king (anno regni regis nunc 28). John Davies seems to have consulted the original case record and stated that it came from a 'Commonplea' roll. Without the heading from the rotulus we cannot definitively identify which court this came from. This case is important because it is the oldest surviving instance when someone claimed that the 'five bloods' were enfranchised by a royal grant. ${ }^{146}$

\footnotetext{
${ }^{146}$ Many thanks to Meg Smith and Paul Brand for their comments on this manuscript.
} 
BL, Add. MS 4790, ff 67v-68r: [Dublin] Simon Neell queritur de Willelmo Newlaghe de Clondolkan de placito quare idem Willelmus vi et armis apud Clondolkan die Lune proxime post festum sancte Margarete virginis anno regni regis nunc xxviii. cum bestiis suis viz affr[is]. [vitulis] ${ }^{147}$ et bidentibus vestur[am] vnius acre prati precii dimidie marce ibidem crescentem pascuit destruxit et calcavit contra pacem, vnde dicit quod deterioratus est et dampnumt dampnum habet ad valenciam viginti solidorum et inde petit remedium etc. Et predictus |Willelmus/ modo venit et dicit quod predictus Simon est Hibernicus et non de quinque sanguinibus et petit judicium si ipse ei inde respondere tenetur; Et predictus Simon dicit quod ipse est de quinque sanguinibus viz dez Oneylys de Vltonia qui per concessionem progenitorum domini regis libertatibus Anglie gaudere debent et vtuntur, Et pro liberis hominibus reputantur, et hoc offert verificare etc. Et predictus Willelmus dicit quod ipse Simon est Hibernicus et non dez Oneylys de Vltonia nec de quinque sanguinibus et hoc offert similiter verificare ideo fiat inde jurata etc. [Qui] ${ }^{148}$ veniunt etc. Et juratores dicunt super sacramentum suum quod predictus Simon est de nacione dez Oneylys de Vltonia et sic est de quinque sanguinibus etc. Juratores [quesiti] ${ }^{149}$ de [dampnis] ${ }^{150}$ dicunt quod ad [dampnum $]^{151}$ sex denarii, Ideo consideratum est quod predictus Simon recuperet versus predictum Willelmum dampna sua predicta et predictus Willelmus comitta[tur] gaole quousque, Et postea predictus Simon cognovit quod satisfactum est ei de [dampnis] ${ }^{152}$ predictis; et predictus Willelmus de gratia etc per adiudicatur ad finem facere cum domino rege pro gaola remittendo per quadraginta denarios per plegium Petri Capuyll finis.

\footnotetext{
${ }^{147}$ vittúlis in MS.

${ }^{148}$ Que in MS.

149 questi in MS.

${ }^{150}$ dampnū in MS.

151 dampna in MS.

152 dampnū in MS.
} 